\title{
Cinegeo
}

International Journal of Environment and Geoinformatics (IJEGEO) is an international, multidisciplinary, peer reviewed, open access journal.

\section{Analyzing the Energy Efficiency Design Index (EEDI) Performance of a Container Ship}

\section{Aydın TOKUŞLU}

\author{
Chief in Editor \\ Prof. Dr. Cem Gazioğlu \\ Co-Editors
}

Prof. Dr. Dursun Zafer Şeker, Prof. Dr. Şinasi Kaya,

Prof. Dr. Ayşegül Tanık and Assist. Prof. Dr. Volkan Demir

Editorial Committee (August 2020)

\begin{abstract}
Assos. Prof. Dr. Abdullah Aksu (TR), Assit. Prof. Dr. Uğur Algancı (TR), Prof. Dr. Bedri Alpar (TR), Prof. Dr. Lale Balas (TR), Prof. Dr. Levent Bat (TR), Prof. Dr. Paul Bates (UK), İrşad Bayırhan (TR), Prof. Dr. Bülent Bayram (TR), Prof. Dr. Luis M. Botana (ES), Assos. Prof. Dr. Gürcan Büyüksalih (TR), Prof. Dr. Nuray Çăglar (TR), Prof. Dr. Sukanta Dash (IN), Dr. Soofia T. Elias (UK), Prof. Dr. A. Evren Erginal (TR), Assoc. Prof. Dr. Cüneyt Erenoğlu (TR), Dr. Dieter Fritsch (DE), Prof. Dr. Çiğdem Göksel (TR), Prof.Dr. Lena Halounova (CZ), Prof. Dr. Manik Kalubarme (IN), Dr. Hakan Kaya (TR), Assist. Prof. Dr. Serkan Kükrer (TR), Assoc. Prof. Dr. Maged Marghany (MY), Prof. Dr. Michael Meadows (ZA), Prof. Dr. Nebiye Musaoğlu (TR), Prof. Dr. Masafumi Nakagawa (JP), Prof. Dr. Hasan Özdemir (TR), Prof. Dr. Chryssy Potsiou (GR), Prof. Dr. Erol Sarı (TR), Prof. Dr. Maria Paradiso (IT), Prof. Dr. Petros Patias (GR), Prof. Dr. Elif Sertel (TR), Prof. Dr. Nüket Sivri (TR), Prof. Dr. Füsun Balık Şanlı (TR), Prof. Dr. Uğur Şanlı (TR), Duygu Ülker (TR), Prof. Dr. Seyfettin Taş (TR), Assoc. Prof. Dr. Ömer Suat Taşkın (US), Dr. İnese Varna (LV), Dr. Petra Visser (NL), Prof. Dr. Selma Ünlü (TR), Assoc. Prof. Dr. İ. Noyan Y1lmaz (AU), Prof. Dr. Murat Yakar (TR), Assit. Prof. Dr. Sibel Zeki (TR)
\end{abstract}


Research Article

\title{
Analyzing the Energy Efficiency Design Index (EEDI) Performance of a Container Ship
}

\author{
Aydin Tokuşlu (iD) \\ Turkish Naval Forces, Ankara, Turkey \\ E-mail: aydintokuslu78@gmail.com
}

How to cite: Tokuslu, A. (2020). Analyzing the Energy Efficiency Design Index (EEDI) Performance of a Container Ship.

International Journal of Environment and Geoinformatics (IJEGEO), 7(2): 114-119. DOI: 10.30897/ijegeo.703255

\begin{abstract}
The International Maritime Organization (IMO) has adopted a new regulation to prevent air pollution from ship emissions which concentrated on reducing green gas emissions from shipping for existing ships, and energy efficiency measures for the new ship. This new regulation imposes a measure which is called Energy Efficiency Design Index (EEDI). This new measure aims to reduce $\mathrm{CO}_{2}$ emissions and global environmental pollution by using fewer fossil fuels and less greenhouse gas emissions. EEDI is an implementation for all new ships larger than 400 GT. In this paper, one of the container ships of the Turkish maritime trade fleet was analysed in terms of energy efficiency performance. The ship`s energy efficiency was found as an energy-efficient. Some practical proposals have been presented to improve ship`s energy efficiency in the short, medium and long term. This study is the first one which focused on one of the container ship energy efficiency.
\end{abstract}

Keywords: IMO, Ships, Energy Efficiency, EEDI, SEEMP

\section{Introduction}

In line with the targets set out in the UN Climate Change Framework Convention and the Kyoto Protocol, the International Maritime Organization (IMO) has adopted a new regulation to prevent air pollution from ship emissions and has implemented Annex VI in the MARPOL 73/78 convention. These new regulations concentrated on reducing green gas emissions from shipping for existing ships, and energy efficiency measures for new ships (Tokuşlu, 2019). According to UNCTAD 2013 report, bulk carriers, tankers, containers, general cargo ships and gas carriers are the main $\mathrm{CO}_{2}$ emission polluters and emits the majority of the total $\mathrm{CO}_{2}$ emissions of the international shipping (Figure 1). These ship types correspond roughly to the ship classification as defined in MEPC 2011.

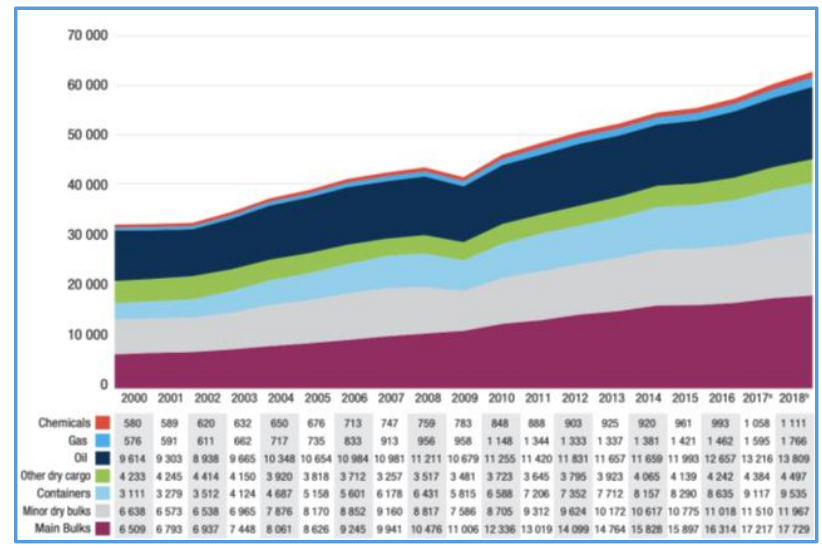

Figure 1. Main $\mathrm{CO}_{2}$ polluters of international shipping (UNCTAD, 2018).
A large number of existing studies in the broader literature have examined these ships emissions and their port emissions such as; (Buhaug et al., 2009; Endresen et al. 2003; Eyring et al., 2009; Corbett et al., 2007; Cohen et al., 2005; Cofala et al., 2007; Wang et al., 2008; Deniz and Kılıç, 2009; EEA, 2013; Viana et al., 2014; Bayirhan et al., 2019; Mersin, 2020) and these studies have emphasized that ship-borne air emissions have harmful impacts on human health and environment and concrete measures should be taken to reduce its` effects. Although there are many studies in ship exhaust gas emissions, the research in the energy efficiency of ships remains limited. The International Maritime Organization (IMO) adopted a new measure in 2011 with a set of technical innovation and performance standards to increase the energy efficiency of new ships at the design stage. This new measure is called Energy Efficiency Design Index (EEDI) and this measure aims to reduce $\mathrm{CO}_{2}$ emissions and global environmental pollution by using fewer fossil fuels and less greenhouse gas emissions. EEDI is an implementation for all new ships larger than $400 \mathrm{GT}$. With this new measure, the new ships will be more energy efficient with its hull optimization, engines, propellers, etc. EEDI enforces minimum energy use and $\mathrm{CO}_{2}$ emission for unit load per ton/mile in different ship types and models in the process from the design stage (IMO, 2011). The smaller the ship's EEDI value, the more energy-efficient the ship is and emits less $\mathrm{CO}_{2}$ emissions. A series of recent studies have indicated that ships energy-efficient measures all are applicable and beneficial for reducing $\mathrm{CO}_{2}$ emissions. 
The literature review shows that EEDI calculation for ships is very important to analyze ships ${ }^{\prime} \mathrm{CO}_{2}$ emissions and understand their energy efficiency regarding their impacts on the environment. Ancic and Sestan (2015) estimated the $\mathrm{CO}_{2}$ emission from bulk carriers based on the current reduction factor change policy. Other policies and some innovative approaches were also discussed and the $\mathrm{CO}_{2}$ emission in every scenario was estimated. Jack (2011) studied the impact of the energy efficiency design index (EEDI) on very large crude carriers' (VLCCs) $\mathrm{CO}_{2}$ emissions. They found that over a market cycle, imposition of EEDI would result in a slight increase in VLCC $\mathrm{CO}_{2}$ emissions, relative to no regulation at all. They concluded that a $\$ 50$ per ton $\mathrm{CO}_{2}$ bunker tax would reduce VLCC $\mathrm{CO}_{2}$ emissions by more than $6 \%$ over a market cycle, and it would do so without forcing the world to devote $30 \%$ more resources to a greatly expanded, under-powered, overdriven VLCC fleet. Attah and Bucknall (2015) analyzed future powering options for LNG carriers when considering the Energy Efficiency Design Index (EEDI) and investigated the impacts of this upcoming EEDI regulation, due to be enforced from September 2015, would have on the design of future LNGCs. They found that the current EEDI reference baseline was insufficient to stimulate improvements in the design of future LNGCs because the current Dual Fuel Diesel Electric (DFDE) propulsion proposed to be installed on the majority of future LNGCs orders already achieves EEDI values that are compliant with the EEDI baseline. They also proposed methods to include methane slip emissions into the current EEDI calculations. Longva et al. (2010) presented a new approach where a required index level (IR) was determined through a cost-effectiveness assessment of the available reduction measures. They analyzed the new panamax bulk carrier ship with using eleven emission reduction measures. They concluded that the costs imposed by new requirements could be justified on the basis of the achievable emission reductions and cross-sector potential for achieving a global reduction target. Tien (2015) calculated the EEDI Index for the bulk carrier with ship name M/V Jules Garnier in the Field of Ship Energy Efficiency and presented measures to improve ship energy efficiency. They offered some reducing measures to be implemented. Zakaria and Rahman (2016) evaluated EEDI for inland vessels in Bangladesh. They assessed 526 cargo ships, 247 passenger ships, 70 oil tankers, and 36 ferries in terms of $\mathrm{CO}_{2}$ emission. The effect of EEDI concerning vessel draft, type of fuel, block coefficient, specific fuel consumption (SFC) and power has been investigated and some viable recommendations have been proposed to reduce the detrimental effects of $\mathrm{CO}_{2}$ emission by optimizing hull shape of some existing vessels. Overall, all these studies focused on the energy efficiency of the existing and new ships and showed the application of the EEDI implementations under the approved amendments to MARPOL Annex 6.

The Turkish maritime trade fleet ranks 20th in the world and consists of 1260 ships above 300 tonnes such as general cargo, bulk carriers, container ships, oil and gas tankers, passenger ships, service vessels, tugs, fishing ship, and yachts. Turkish container transport ranks 15 th in the world container fleet with its 57 ship (UNCTAD, 2018) and transportation capacity of Turkey's container carryings by seaway was 4.4 million TEU in 2009; in 2018 it enhanced 9.9 million TEU, at the same period imports cargoes boosted to 4.2 million TEU from 2.1 million TEU and the exports cargoes enlarged to 4.1 million TEU when compared with 2.1 million TEU in 2009 (TCS, 2019). Container transportation has an important place in the Turkish trade fleet and its capacity is increasing every day. Examining the energy efficiency of container ships is important to see if MARPOL EEDI implementations are applied. Until now, the energy efficiency of the container ships in the Turkish maritime trade fleet has not been examined. In order to close the gap in this area and to examine the status of container ships, container ship was preferred in this analysis. In this study, one of the container ships has been examined since the necessary data for analysis is provided easily. Energy efficiency of the ship was calculated according to IMO regulations and some useful proposals have been presented.

\section{Materials and Methods}

The EEDI implementation covers the designated types of ships, which have the largest and most fuel consumption of the shipping and aims to make $72 \%$ of the merchant fleet energy efficient. Ships with diesel, electric, steam, and hybrid propulsion systems are not included in this implementation. Ship types to which EEDI will be applied;
a. Oil tankers,
b. Bulk carriers,
c. Gas carriers,
d. General cargo,
e. Container ships,
f. Refrigerated cargo,
g. Combination carriers,
h. Roro cargo ship,
i. Roro passenger ship,
j. $\quad$ Cruise passenger ship (ICCT, 2007).

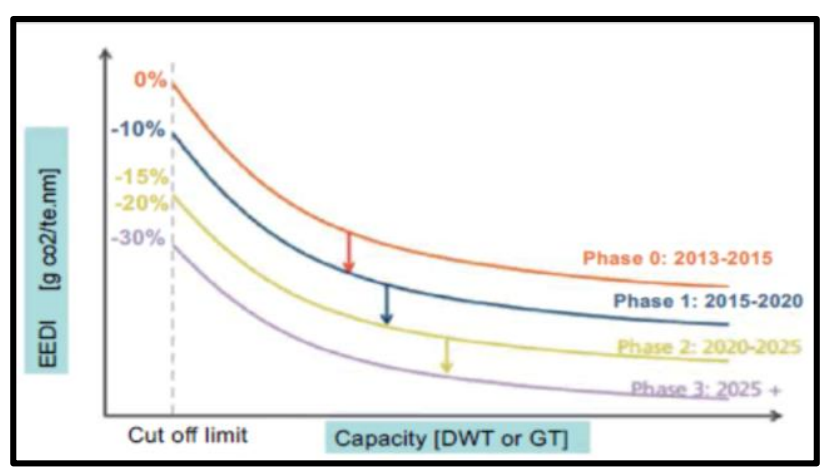

Figure 2. EEDI phases and cut off limits (IMO, 2010)

EEDI implementation tools came into force as of January 01, 2013, and energy efficiency plans have been made every 5 years depending on the new technical and operational solutions for the new ships. The EEDI phases and cut off-limits is shown in Figure 2. Energy efficiency in the first phase is aimed at $10 \%$ and it is 
planned to raise it to $30 \%$ by 2030 . This proportion is anticipated to increase to $50 \%$ by 2050 .

\subsection{Calculation method}

EEDI calculation module was included in Marpol Annex VI with the directive MEPC.1 / Circ.681 at MEPC meeting held by IMO in 2011 and it has been put into effect as of January 01, 2013. The EEDI formula (1) (IMO, 2011) consists of the following equation;

$$
E E D I=\frac{\mathrm{P} * \mathrm{SFC} * \mathrm{Cf}}{\mathrm{DWT} * \text { Vref }}
$$

$\mathrm{P} \quad: 70 \%$ of the power of the engine (main and auxiliary) in $\mathrm{kW}$

SFC : Amount of fuel burned by the engines in $\mathrm{kW}$ (specific fuel consumption)

Cf : Emission rate of fuel used by the ship (presented in Table 1)

DWT : Ship's capacity (in tons)

Vref : speed of the ship (in knots)

Table 1. Carbon content and $\mathrm{C}_{\mathrm{F}}$ values of different types of fuel (MEPC 245 (66), 2014)

\begin{tabular}{|c|c|c|c|}
\hline Type of fuel & Reference & $\begin{array}{l}\text { Carbon } \\
\text { Content }\end{array}$ & $\begin{array}{c}\mathrm{C}_{\mathrm{F}} \\
\left(\mathrm{t}-\mathrm{CO}_{2} / \mathrm{t}-\right. \\
\text { Fuel })\end{array}$ \\
\hline $\begin{array}{l}\text { Diesel / Gas } \\
\text { Oil }\end{array}$ & $\begin{array}{lr}\text { ISO } & 8217 \\
\text { Grades } & \text { DMX } \\
\text { through } & \text { DMB }\end{array}$ & 0.8744 & 3.206 \\
\hline $\begin{array}{l}\text { Light Fuel } \\
\text { Oil (LFO) }\end{array}$ & $\begin{array}{lr}\text { ISO } & 8217 \\
\text { Grades } & \text { RMA } \\
\text { through } & \text { RMD }\end{array}$ & 0.8594 & 3.151 \\
\hline $\begin{array}{l}\text { Heavy Fuel } \\
\text { Oil (HFO) }\end{array}$ & $\begin{array}{lr}\text { ISO } & 8217 \\
\text { Grades } & \text { RME } \\
\text { through } & \text { RMK }\end{array}$ & 0.8493 & 3.114 \\
\hline $\begin{array}{l}\text { Liquefied } \\
\text { Petroleum } \\
\text { Gas (LPG) }\end{array}$ & $\begin{array}{l}\text { Propane } \\
\text { Butane }\end{array}$ & $\begin{array}{l}0.8182 \\
0.8264\end{array}$ & $\begin{array}{l}3.000 \\
3.030\end{array}$ \\
\hline $\begin{array}{l}\text { Liquefied } \\
\text { Natural Gas } \\
\text { (LNG) }\end{array}$ & & 0.7500 & 2.750 \\
\hline Methanol & & 0.3750 & 1.375 \\
\hline Ethanol & & 0.5217 & 1913 \\
\hline
\end{tabular}

The detailed explanations of the EEDI formula are presented are at IMO MEPC Resolution 245 (66) which consists of different constants and coefficients. When we calculated the EEDI according to this equation (1) for the target ship, the attained EEDI can be found. The reference EEDI must be bigger than the attained EEDI, if the reference EEDI doesn't exceed the attained EEDI, the ship is considered energy efficient. we can calculate the reference EEDI (2) with the formula stated below;

The reference EEDI $=a \times b^{-c}$

Reference line value ( $a, b$ and $c)$ parameters are presented in Table 2. The reference line values are provided from the vessel database of Lloyd's Register Fair play. Sample reference lines for ship types are shown in Figure 3 which was created from Lloyd's
Register Fair play database (IMO, 2011). Table 3 presents us with EEDI reduction factors and cut off limits through implementation phases. EEDI reduction factors and cut off limits will help us to calculate the required EEDI based on the year of the ship built. The required EEDI must be bigger than the attained EEDI (the attained EEDI $\leq$ the required EEDI).

Table 2. Reference line value ( $a, b$ and $c$ ) parameters (the reference EEDI) (IMO, 2011)

\begin{tabular}{lccc}
\hline $\begin{array}{l}\text { Ship type defined in } \\
\text { regulation }\end{array}$ & a & b & c \\
\hline Bulk carrier & 961.79 & DWT & 0.477 \\
Gas tanker & 1120 & DWT & 0.456 \\
Tanker & 1218.8 & DWT & 0.488 \\
Container ship cargo & 227.01 & DWT & 0.244 \\
$\begin{array}{l}\text { General cargo ship } \\
\text { Refrigerated }\end{array}$ & 174.22 & DWT & 0.201 \\
carrier & 1219 & DWT & 0.488 \\
$\begin{array}{l}\text { Combination carrier } \\
\text { Roro cargo ship }\end{array}$ & 1405.15 & DWT & 0.498 \\
$\begin{array}{l}\text { Roro passenger ship } \\
\text { LNG carrier }\end{array}$ & 752.16 & DWT & 0.381 \\
$\begin{array}{l}\text { Cruise passenger ship } \\
\text { having non-conventional } \\
\text { propulsion }\end{array}$ & 170.84 & GRT & 0.474 \\
\end{tabular}

Table 3. EEDI reduction factors and cut off limits through implementation phases (MEPC, 203 (62), 2011)

\begin{tabular}{|c|c|c|c|c|c|}
\hline Ship Type & Size & \begin{tabular}{|c|} 
Phase 0 \\
1Jan 2013- \\
31 Dec \\
2014
\end{tabular} & $\begin{array}{c}\text { Phase } 1 \\
1 \text { Jan } \\
2015- \\
31 \text { Dec } \\
2019\end{array}$ & $\begin{array}{c}\text { Phase } 2 \\
1 \text { Jan } \\
2020-31 \\
\text { Dec } 2024\end{array}$ & $\begin{array}{l}\text { Phase } 3 \\
1 \text { Jan } \\
2025 \text { and } \\
\text { onwards }\end{array}$ \\
\hline \multirow{2}{*}{ Bulk carrier } & $\begin{array}{c}20,000 \text { DWT and } \\
\text { above }\end{array}$ & 0 & 10 & 20 & 30 \\
\hline & $\begin{array}{c}10,000 \text { DWT and } \\
\text { above }\end{array}$ & $\mathrm{n} / \mathrm{a}$ & $0-10^{\circ}$ & $0-20^{\circ}$ & $0-30^{\circ}$ \\
\hline \multirow[t]{2}{*}{ Gas carrier } & $\begin{array}{c}10,000 \text { DWT and } \\
\text { above }\end{array}$ & 0 & 10 & 20 & 30 \\
\hline & $2,000-10,000 \mathrm{DWT}$ & $\mathrm{n} / \mathrm{a}$ & $0-10^{\circ}$ & $0-20^{\circ}$ & $0-30^{\circ}$ \\
\hline \multirow{2}{*}{ Tanker } & $\begin{array}{l}20,000 \text { DWT and } \\
\text { above }\end{array}$ & 0 & 10 & 20 & 30 \\
\hline & $\begin{array}{c}4,000-20,000 \\
\text { DWT }\end{array}$ & $\mathrm{n} / \mathrm{a}$ & $0-10^{\circ}$ & $0-20^{\circ}$ & $0-30^{\circ}$ \\
\hline \multirow{2}{*}{ Container ship } & $\begin{array}{c}15,000 \text { DWT and } \\
\text { above }\end{array}$ & 0 & 10 & 20 & 30 \\
\hline & $\begin{array}{c}10,000-15,000 \\
\text { DWT }\end{array}$ & $\mathrm{n} / \mathrm{a}$ & $0-10^{\circ}$ & $0-20^{\circ}$ & $0-30^{\circ}$ \\
\hline \multirow{2}{*}{$\begin{array}{l}\text { General Cargo } \\
\text { ships }\end{array}$} & $\begin{array}{c}15,000 \text { DWT and } \\
\text { above }\end{array}$ & 0 & 10 & 15 & 30 \\
\hline & $3,000-15,000 \mathrm{DWT}$ & $\mathrm{n} / \mathrm{a}$ & $0-10^{\circ}$ & $0-15^{\circ}$ & $0-30^{\circ}$ \\
\hline \multirow{2}{*}{$\begin{array}{l}\text { Refrigerated } \\
\text { cargo carrier }\end{array}$} & $\begin{array}{c}5,000 \text { DWT and } \\
\text { above }\end{array}$ & 0 & 10 & 15 & 30 \\
\hline & $3,000-5,000$ DWT & $\mathrm{n} / \mathrm{a}$ & $0-10^{\circ}$ & $0-15^{\circ}$ & $0-30^{\circ}$ \\
\hline \multirow[t]{2}{*}{$\begin{array}{l}\text { Combination } \\
\text { carrier }\end{array}$} & $\begin{array}{c}20,000 \text { DWT and } \\
\text { above }\end{array}$ & 0 & 10 & 20 & 30 \\
\hline & $4,000-20,000 \mathrm{DWT}$ & $\mathrm{n} / \mathrm{a}$ & $0-10^{\circ}$ & $0-20^{\circ}$ & $0-30^{\circ}$ \\
\hline LNG carrier ${ }^{* \cdots}$ & $\begin{array}{c}10,000 \text { DWT and } \\
\text { above }\end{array}$ & $\mathrm{n} / \mathrm{a}$ & $10^{*}$ & 20 & 30 \\
\hline $\begin{array}{l}\text { Ro-Ro cargo } \\
\text { ship (vehicle } \\
\text { carrier)"' }\end{array}$ & $\begin{array}{c}\text { 10,000 DWT and } \\
\text { above }\end{array}$ & $\mathrm{n} / \mathrm{a}$ & 5 & 15 & 30 \\
\hline \multirow{2}{*}{$\begin{array}{l}\text { Ro-Ro cargo } \\
\text { ship }{ }^{*}\end{array}$} & $\begin{array}{l}2,000 \text { DWT and } \\
\text { above }\end{array}$ & $\mathrm{n} / \mathrm{a}$ & $5 *$ & 20 & 30 \\
\hline & $1,000-2,000$ DWT & $\mathrm{n} / \mathrm{a}$ & $0-5^{*}, \cdot$ & $0-20^{\circ}$ & $0-30^{\circ}$ \\
\hline \multirow{2}{*}{$\begin{array}{l}\text { Ro-Ro } \\
\text { passenger } \\
\text { ship }\end{array}$} & $\begin{array}{l}1000 \text { DWT and } \\
\text { above }\end{array}$ & $\mathrm{n} / \mathrm{a}$ & $5 *$ & 20 & 30 \\
\hline & 250-1,000 DWT & $\mathrm{n} / \mathrm{a}$ & $0-5, \cdot$ & $0-20^{\circ}$ & $0-30^{\circ}$ \\
\hline \multirow{2}{*}{$\begin{array}{c}\text { Cruise } \\
\text { passenger } \\
\text { ship } \\
\text { having non- } \\
\text { conventional } \\
\text { propulsion }\end{array}$} & $\begin{array}{l}85,000 \mathrm{GT} \text { and } \\
\text { above }\end{array}$ & $\mathrm{n} / \mathrm{a}$ & $5 *$ & 20 & 30 \\
\hline & $25,000-85,000 \mathrm{GT}$ & $\mathrm{n} / \mathrm{a}$ & $0-5^{*}, \cdot$ & $0-20^{\circ}$ & $0-30^{\circ}$ \\
\hline
\end{tabular}



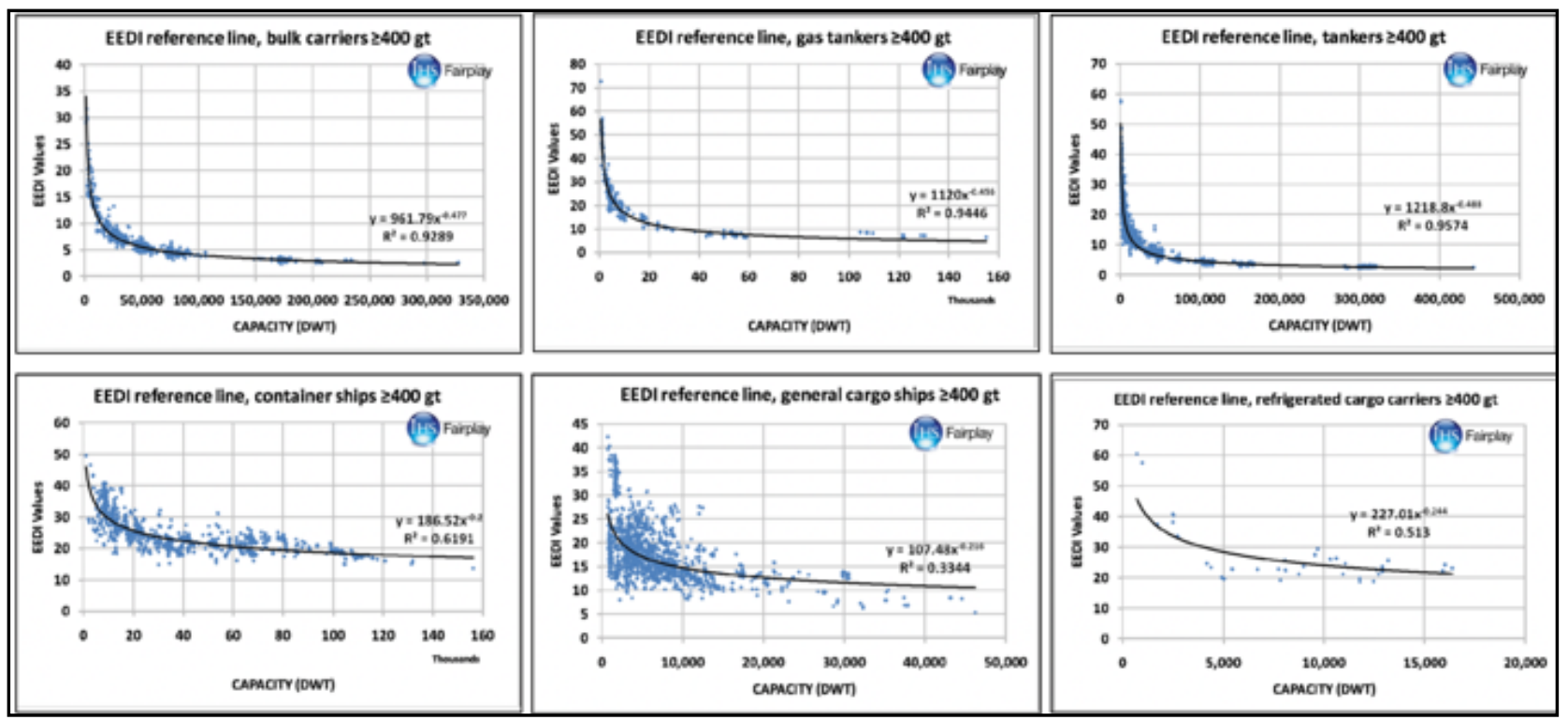

Figure 3. Sample reference lines for ship types (MEPC 62/6/4, 2011)

\subsection{Ship particulars}

The vessel studied in this present work is the container ship M/V Leyla Kalkavan (9126924)(Figure 4) which was built in 1997 with hull number 109 in Turkey and is sailing under the flag of Turkey. This ship is an average ship in Turkish container fleet and it was chosen because the necessary data for analysis is provided easily. Ship particulars for the study are;

- Length: 136,8 m

- Breadth : 22,7 m

- Draught: 7,7 m

- Deadweight (DWT) : 12.205 tons (1155 TEU)

- Tonnage Gross: 10384 tons

- Tonnage Net: 5070 tons

- Main engine type: Mitsubishi (2-stroke)

- Main engine power (MCR): $10.092 \mathrm{~kW}$

- Service speed: 16 knots

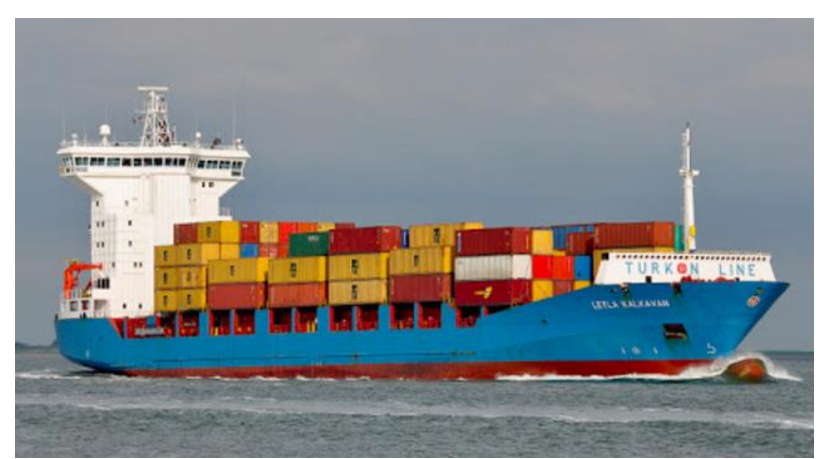

Figure 4. M/V Leyla Kalkavan

\section{Results}

The reference EEDI and the attained EEDI of the ship was calculated using equation 1 and 2 with the data we obtained. The attained EEDI must be less than the reference EEDI for the ship to be considered energy efficient. According to ship particulars, the reference EEDI can be calculated as;
The reference EEDI $=\mathrm{a} \times \mathrm{b}^{-\mathrm{c}}=174,22 \times 12205^{-0,201}=$ $26,285\left(\mathrm{gCO}_{2} /\right.$ ton.mile $)$

The attained EEDI must be smaller than the required EEDI (the attained EEDI $\leq$ the required EEDI). For container ships, $70 \%$ of the deadweight (DWT) is used as the capacity for calculation of $\mathrm{P}_{\mathrm{ME}}$ (MEPC 66/21; IMO, 2012). For the target ship, $\mathrm{P}_{\mathrm{ME}}$ is found $7064 \mathrm{~kW}$. While the main engine power (MCR) is above the $10.000 \mathrm{~kW}, \mathrm{P}_{\mathrm{AE}}$ can be calculated as $\mathrm{P}_{\mathrm{AE}}=(0,025 \mathrm{x}$ MCR) +250 and $\mathrm{P}_{\mathrm{AE}}$ is found $502,3 \mathrm{~kW}$. The ship is using heavy fuel oil (HFO) and its emission factor $\mathrm{C}_{\mathrm{F}}$ is 3.114. Fuel consumption burned by the main engine of heavy fuel oil (HFO) is $190 \mathrm{~kW}$ and by the auxiliary engine of heavy fuel oil (HFO) is $215 \mathrm{~kW}$. Calculation of the attained EEDI and required EEDI is;

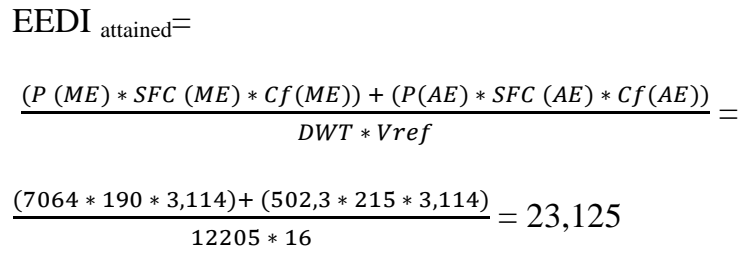

$\mathrm{EEDI}_{\text {required }}=(1$-reduction factor/100) $\mathrm{x}$ reference EEDI= $(1-10 / 100) \times 26,285=23,657$

Since the reference EEDI is larger than the calculated attained EEDI, this ship can be considered as energyefficient ship and emits less $\mathrm{CO}_{2}$. This vessel doesn't exceed its EEDI value and doesn't need to be implemented EEDI reduction measures. Table 4 presents different calculation times according to different main engine load and Figure 5 shows EEDI $\left(\mathrm{gCO}_{2} /\right.$ ton-mile) on M/V Leyla Kalkavan based on main engine load results. It can be concluded from calculations that the target ship meets the EEDI criteria. 
Table 4. Calculation times according to main engine load on M/V Leyla Kalkavan

\begin{tabular}{lccccc}
\hline $\begin{array}{l}\text { Main } \\
\text { Engine } \\
\text { Load }\end{array}$ & $\begin{array}{c}\text { Calculation } \\
\text { times }\end{array}$ & $\begin{array}{c}\text { Main } \\
\text { Engine } \\
\text { Output } \\
(\mathrm{kW})\end{array}$ & $\mathrm{C}_{\mathrm{F}}$ & $\mathrm{DWT}$ & $\begin{array}{c}\text { Speed } \\
(\mathrm{knots})\end{array}$ \\
\hline $\begin{array}{l}100 \% \\
(\max )\end{array}$ & $\mathrm{C}-1$ & 10.092 & 3,114 & 12.205 & 16 \\
$90 \%$ & $\mathrm{C}-2$ & 9.083 & 3,114 & 12.205 & 15 \\
$80 \%$ & $\mathrm{C}-3$ & 8.074 & 3,114 & 12.205 & 14 \\
$70 \%$ & $\mathrm{C}-4$ & 7.064 & 3,114 & 12.205 & 13 \\
$60 \%$ & $\mathrm{C}-5$ & 6.055 & 3,114 & 12.205 & 12 \\
$50 \%$ & $\mathrm{C}-6$ & 5.046 & 3,114 & 12.205 & 11
\end{tabular}

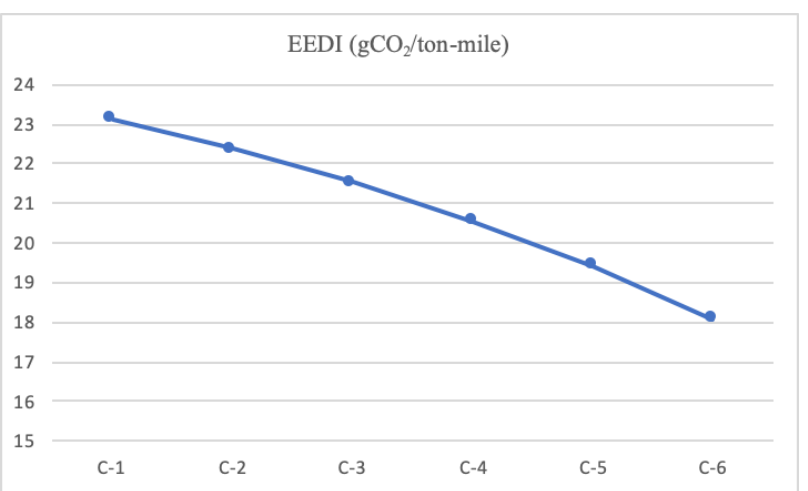

Figure 5. EEDI ( $\mathrm{gCO}_{2} /$ ton-mile) on M/V Leyla Kalkavan based on the main engine load.

It can be concluded from Table 4 and Figure 5, EEDI $_{\text {attained }}$ value decreases with decreasing speed. it can also be seen that the main engine power $\left(\mathrm{P}_{\mathrm{ME}}\right)$ decreases with decreasing speed. This means that speed reduction gives a better performance in terms of EEDI, the ship becomes more energy efficient and the ship emits less $\mathrm{CO}_{2}$ emission. The ship definitely must navigate with the speed of 11 or 12 knots which is the economic speed.

\section{Discussion and Conclusion}

In this study, a container ship was analyzed in terms of energy efficiency performance. According to calculations, the ship was found an energy-efficient ship. The ship was built in 1997 and it wasn't under the mandatory regulation of MARPOL EEDI. Ship Energy Efficiency Management Plan (SEEMP) covers all types of ships so that SEEMP measures can be applied to keep the ship energy efficient. SEEMP measures can be implemented for better performance, and these measures will help to improve energy efficiency in the short, medium and long term, measures can be stated such as;

- alternative fuels such as LNG, LPG, gas oil can be used which will make $3-4 \%$ reduction,

- for the less resistance, hull optimization should be reviewed and underwater hull coatings and monitoring should be done periodically (4-5\% reduction),

- speed reduction should be continued to get better EEDI performance (10-15\% reduction)

- hull and propeller should be cleaned periodically (5-10\% reduction),

- exhaust gas waste heat recovery of main and auxiliary engines` should be implemented (15-20\% reduction),
- weather routing such as avoiding rough seas and head currents should be implemented for voyage efficiency (4-6\% reduction).

All these measures will help to keep the attained EEDI less than 23,125 $\mathrm{gCO}_{2}$ /ton.mile and the ship will be energy efficient. For the future, shipyards or ship designers should follow the EEDI implementations for the new energy-efficient ships. In the Turkish maritime trade fleet, generally all the container ships have the same specifications like age, size, tonnage, and speed. In general, there are some easy applications that all container ships can implement to maintain energy efficiency. It is evaluated that speed reduction application can be made easily in the beginning of these applications. The use of alternative fuels such as LNG, LPG, kerosene should definitely be encouraged. Boat and propeller cleaning should be done periodically, boat optimization and underwater hull coatings should be checked regularly.

\section{Conflict of interest statement}

I declare that I have no conflict of interest.

\section{References}

Ancic, I., Šestan, A. (2015). Influence of the required EEDI reduction factor on the $\mathrm{CO}_{2}$ emission from bulk carriers. Energy Policy 84 (2015) 107-116. http://dx.doi.org/10.1016/j.enpol.2015.04.031.

Attah, E.E., Bucknall, R. (2015). An analysis of the energy efficiency of LNG ships powering options using the EEDI. Ocean Engineering 110 (2015) 6274. http://dx.doi.org/10.1016/j.oceaneng.2015.09.040

Bayirhan, I., Mersin, K., Tokuşlu, A., Gazioğlu, C., (2019). Modelling of Ship Originated Exhaust Gas Emissions in the Istanbul Strait. International Journal of Environment and Geoinformatics, 6(3): 238-243 https://doi.org/10.30897/ijegeo.641397.

Buhaug, Ø., Corbett, J.J., Endersen, Ø., Eyring, V., Faber, J., Hanayama, S., Lee, D.S., Lee, D., Lindstad, H., Mjelde, A., Palsson, C., Wanquing, W., Winebrake, J.J., Yoshida, K. (2009). Updated study on greenhouse gas emissions from ships. Second IMO GHG Study. London, UK: International Maritime Organization.

Cofala, J., Amann, M., Heyes, C., Klimont, Z., Posch, M., Scho pp, W., Tarasson, L., Jonson, J., Whall, C., Stavrakaki, A. (2007). Final Report: Analysis of Policy Measures to Reduce Ship Emissions in the Context of the Revision of the National Emissions Ceilings Directive. International Institute for Applied Systems Analysis, Laxenburg, Austria, p. 74.

Cohen, A.J., Anderson, H.R., Ostro, B., Pandey, K.D., Krzyzanowski, M., Künzli, N., Gutschmidt, K., Pope, A., Romieu, I., Samet, J.M., Smith, K. (2005). The global burden of disease due to outdoor air pollution. J. Toxicol. Environ. Health, Part. A 68, 1301-1307.

Corbett, J.J., Winebrake, J.J., Green, E.H., Kasibhatla, P., Eyring, V., Lauer, A. (2007). Mortality from ship emissions: a global assessment. Environmental 
Science \& Technology 41 (24), 8512-8518. doi: 10.1021/es071686z.

Deniz, C., Kılıç, A. (2009). Estimation and assessment of shipping emissions in the region of Ambarl1 Port, Turkey. Environ. Prog. Sustain. Energy 107e115. http://dx.doi.org/10.1002/ep.10373.

Endresen, Ø., Sørgard, E., Sundet, J. K., Dalsøren, S. B., Isaksen, I. S. A., Berglen, T. F., and Gravir, G. (2003). Emission from international sea transportation and environmental impact, J. Geophys. Res., 108(D17), 4560, doi:10.1029/2002JD002898, 2003.

European Environment Agency (EEA). (2013). The Impact of International Shipping on European Air Quality and Climate Forcing. EEA, Copenhagen, p. 88.

Eyring, V., Isaksen, I., Berntsen, T., Collins, W., Corbett, J., Endresen, O., Grainger, R., Moldanova, J., Schlager, H., Stevenson, D. (2009). Transport impacts on atmosphere and climate: Shipping. Atmospheric Environment 44 (2010) 4735-4771. http://dx.doi.org/10.1016/j.atmosenv.2009.04.059.

International Maritime Organization (IMO). (2009). Resolution MEPC.1/Circ.681, Interim Guidelines On The Method Of Calculation Of The Energy Efficiency Design Index For New Ships, 2009.

International Maritime Organization (IMO). (2010). Module 2 - Ship Energy Efficiency Regulations and Related Guidelines", IMO Train the Trainer (TTT) Course on Energy Efficient Ship Operation.

International Maritime Organization (IMO). (2011). Reduction of GHG Emissions from Ships, Detail Treatment of İnnovative Energy Efficiency Technologies for Calculation of the Attained EEDI. Marine Environment Protection Committee Meeting, London,UK.

International Maritime Organization (IMO). (2012). Interim guidelines for the calculation of the coefficient fw for decrease in ship speed in a representative sea condition for trial use. MEPC.1/Circ.796.

Jack, D. (2011). The impact of the energy efficiency design index on very large crude carrier design and $\mathrm{CO}_{2}$ emissions, Ships and Offshore Structures, 6:4, 355-368, DOI: 10.1080/17445302.2010.546651

Longva, T., Eide, M.S., Skjong, R. (2010). Determining a required energy efficiency design index level for new ships based on a cost-effectiveness criterion. Marit. Pol. Mgmt., 37(2), 129-143. DOI: 10.1080/03088830903533759

MEPC (2011). Report of the Marine Environment Protection Committee on its Sixty-Second Session, MEPC 62/24, London, UK.

MEPC 62/6/4. (2011). Marine Environment Protection Committee, Consideration and Adoption of Amendments to Mandatory Instruments, Calculation of Parameter for determination of EEDI reference values, 2011.

MEPC 66/21/Add.1, Annex 5. (2014). Guidelines on the Method of Calculation of the Attained Energy Efficiency Design Index (EEDI) for New Ships, 2014.
MEPC Resolution 245 (66). (2014). Guideline on the Method of Calculation of the Attained Energy Efficiency Design Index (EEDI) for New Ships, 2014.

MEPC.203(62). (2011). Amendments to the Annex of the Protocol of 1997 to Amend the International Convention for the Prevention of Pollution from Ships, 1973, As Modified by the Protocol of 1978 Relating Thereto.

Mersin, K. (2020). A New Method for Calculating Fuel Consumption by Using Speed Loss Function. International Journal of Environment and Geoinformatics, 7 (1), 64-67, DOI: 10.30897/ijegeo.700557

The International Council on Clean Transportation (ICCT). (2007). Air Pollution and Greenhouse Gas Emissions From Ocean-Going Ships: Impacts, Mitigation Options and Opportunities for Managing Growth. Washington, USA: The International Council on Clean Transportation Publications.

Tien, A.T. (2015). Calculation and Assessing the EEDI Index in the Field of Ship Energy Efficiency for M/V Jules Garnier. Journal of Marine Science: Research \& Development, 6(6), DOI: 10.4172/21559910.1000212.

Tokuşlu, A. (2019). Analysis of ship-borne air emissions in the Istanbul Strait and presenting its effects. ( $\mathrm{PhD}$ thesis). Istanbul University, Istanbul, Turkey

Turkish Chamber of Shipping (TCS). (2019). Maritime Sector Report. 140p.

United Nations Conference on Trade and Development (UNCTAD). (2018). Review of Maritime Transport. UNCTAD/RMT/2018. ISBN 978-92-1-112928-1

Viana, M., Hammingh, P., Colette, A., Querol, X., Degraeuwe, B., Vlieger, I.D., Aardenne, J.V. (2014). Impact of maritime transport emissions on coastal air quality in Europe. Atmos. Environ. 90: 96-105, DOI: /10.1016/j.atmosenv.2014.03.046.

Wang, C., Corbett, J.J., Firestone, J. (2008). Modeling energy use and emissions from North American shipping: application of ship traffic, energy and environment model. Environmental Science \& Technology 42 (1), 193-199.

Zakaria, N.M.G., Rahman, S. (2016). Energy Efficiency Design Index (EEDI) for Inland Vessels in Bangladesh. Procedia Engineering 194: 362 - 369. DOI: $10.1016 /$ j.proeng.2017.08.158. 